\title{
Prevalence of Listeria species in some foods and their rapid identification
}

\author{
Hany M Yehia ${ }^{1,2 \star}$, Shimaa M Ibraheim ${ }^{3}$ and Wesam A Hassanein ${ }^{3}$ \\ ${ }^{1}$ Food Science and Nutrition Department, college of Food and Agriculture Sciences, King Saud University, Alriyadh, Saudi \\ Arabia, ${ }^{2}$ Food Science and Nutrition, Faculty of Home Economics, Helwan University, Cairo, ${ }^{3}$ Department of Botany \\ (Microbiology), Faculty of Science, Zagazig University, Zagazig, Egypt
}

*For correspondence: Email: hanyehia@ksu.edu.sa, hanyyehia43@yahoo.de; Tel: 009660509610654

Received: 21 August 2015

Revised accepted: 13 April 2016

\begin{abstract}
Purpose: To investigate the occurrence of Listeria spp., (particularly L. monocytogenes), in different foods and to compare diagnostic tools for their identification at species level.

Methods: Samples of high protein foods such as raw meats and meat products and including beef products, chicken, fish and camel milk were analysed for the presence of Listeria spp. The isolates were characterised by morphological and cultural analyses, and confirmed isolates were identified by protein profiling and verified using API Listeria system. Protein profiling by SDS-PAGE was also used to identify Listeria spp.

Results: Out of 40 meat samples, 14 (35\%) samples were contaminated with Listeria spp., with the highest incidence $(50 \%)$ occurring in raw beef products and raw chicken. Protein profiling by SDSPAGE was used to identify Listeria spp. The results were verified with API Listeria system. Approximately $25 \%$ of the identified isolates were Listeria seeligeri, Listeria welshimeri, and Listeria grayi (three positive samples), while $16.66 \%$ of the isolates were Listeria monocytogenes (two positive samples); $16.6 \%$ of the isolates were Listeria innocua (two positive samples), while $8.3 \%$ of the isolates were Listeria ivanovii (one positive sample).

Conclusion: High protein foods contain different types of Listeria species; whole-cell protein profiles and API Listeria system can help in the identification of Listeria at the species level.
\end{abstract}

Keywords: Listeria spp, High protein food, Api Listeria, Protein profile

Tropical Journal of Pharmaceutical Research is indexed by Science Citation Index (SciSearch), Scopus, International Pharmaceutical Abstract, Chemical Abstracts, Embase, Index Copernicus, EBSCO, African Index Medicus, JournalSeek, Journal Citation Reports/Science Edition, Directory of Open Access Journals (DOAJ), African Journal Online, Bioline International, Open-J-Gate and Pharmacy Abstracts

\section{INTRODUCTION}

Listeria is a Gram-positive rod-shaped bacterium measuring $0.4-0.5$ by $0.5-2.0 \mu \mathrm{m}$, with rounded ends [1]. It is ubiquitously distributed in nature. These facultative anaerobic bacteria grow in psychotropic, mesophilic environments and occasionally tolerate high temperatures as these may equally grow at low temperatures. These bacteria can be curved, forming single or short chains, often in a "V" shape. Listeria monocytogenes is motile due to one to five peritrichous flagella, which may be lost as the bacteria enter the human cell.

Filaments, ranging 6 - $20 \mu \mathrm{m}$ in size may develop in old cultures. Older cultures may also stain irregularly. The genus Listeria includes 6 species: L. monocytogenes, $L$. innocua, $L$. seeligeri, L. welshimeri, L. ivanovii, and L. grayi. $L$. monocytogenes is considered the only pathogenic species, but scientists have reported three cases of human infection caused by Listeria ivanovii $[2,3]$ and one case of infection caused by Listeria seeligeri [4]. Nevertheless, 
among the six species, $L$. monocytogenes is the only species considered to be of public health $[5,6]$.

L. monocytogenes cause severe in immunocompromised individuals such as pregnant women. In pregnant women listeriosis may cause abortion, fetal death, or neonatal morbidity in the form of septicemia and meningitis [7]. The mortality rate for infants born alive approaches $20 \%$, and the frequency of abortion and stillbirth increases the overall mortality rate to more than $40 \%$ [7]. The presence of any Listeria spp, in foods is an indication of poor hygiene, and increases the probability of presence of $L$. monocytogenes. In Brazil, the occurrence of Listeria spp. was widely demonstrated in vegetables [8], shrimp (9), beef, milk and dairy products $[10,11]$; sewage [12] and soil [13].

Listeria spp. is widespread in the environment, but only $L$. monocytogenes is considered to be a significant human and animal pathogen [16]. Few studies have reported the incidence of the Listeria spp. in meat products in Saudi Arabia. The purpose of the present study was to investigate the occurrence of Listeria spp., particularly $L$. monocytogenes, in raw camel milk and raw meat products, including beef products, chicken, and fish. Whole-cell protein profiles of presumptive Listeria isolates were compared with the reference strains $L$. monocytogenes ATCC 19114 and L. innocua ATCC 33090 on SDS page. High degree of similarity within standard strain was confirmed by biochemical identification using an API Listeria biotyping identification system.

\section{EXPERIMENTAL}

\section{Materials}

A total of 40 food samples, including raw beef products (10), raw chicken (10), raw fish (10) and raw camel milk (10) were obtained from a wholesale poultry market located in the northern part of Riyadh City, Saudi Arabia. The samples were transported at refrigeration temperature to the Food Microbiology Laboratory, College of Food and Agricultural Sciences, King Saud University

\section{Detection and isolation procedure}

Listeria spp. were isolated from samples using cotton swabs and directly inoculated in test tubes containing $10 \mathrm{ml}$ of Listeria-selective enrichment broth base (Oxoid, CM0862, Oxoid Limited, United Kingdom) supplied with selective enrichment supplements (Oxoid, SR0141). The culture was incubated at $37^{\circ} \mathrm{C}$ for $24 \mathrm{~h}$.

A single loop of bacteria was obtained from the enrichment broth and streaked onto Listeriaselective agar media (Oxoid, CM0856) containing selective supplements (Oxoid, SR0140). The plates were incubated at $37^{\circ} \mathrm{C}$ for 24 - 48 h. Colonies morphologically resembling Listeria spp. were submitted for confirmatory examinations using Gram staining. The bacteria were further subjected to protein extraction using different enzymes.

\section{Preparation of cell extract}

An overnight culture of Listeria isolates was inoculated into fresh medium (Brain heart infusion broth, Oxoid, CM1135) and grown to an optical density (OD-620) of 0.6 to 0.8 (3 to $4 \mathrm{~h}$ ). The cells were collected and weighed, and 250 mg of cells suspended in $100 \mu \mathrm{L}$ of a TES buffer (50 mM Tris- $\mathrm{HCl}, \mathrm{pH} 8,1 \mathrm{mM}$ EDTA, and $25 \%$ sucrose). Approximately $10 \mu \mathrm{L}$ of lysozyme (50 $\mathrm{mg} / \mathrm{mL}$ ) and $5 \mu \mathrm{L}$ of mutanolysin $(5000 \mu / \mathrm{mL})$ were added to the suspended cells in TES buffer and incubated at $37^{\circ} \mathrm{C}$ for $30 \mathrm{~min}$.

Approximately 5 - $10 \mu \mathrm{L}$ of $20 \%$ SDS were added, and the contents were mixed until the suspension of the cell proteins became clear. The contents were used directly for separation in SDS-PAGE (12\% acrylamide) or stored at -20 ${ }^{\circ} \mathrm{C}$ for 1 to $2 \mathrm{~d}$ until further use.

Fifty microlitre extracts (references and isolated bacteria) were added to $4 \mathrm{X}$ protein loading buffer (Roth, K929.2) and were subsequently assessed with SDS-PAGE. Electrophoresis was performed at $25{ }^{\circ} \mathrm{C}$ in a vertical tank apparatus, using a constant-voltage power supply, until the bromophenol blue tracking dye reached the bottom of the gel. The gels were stained with $0.25 \%$ Coomassie Brilliant Blue R-250 (Bio-Rad) in water: methanol: acetic acid (6.5: 2.5: $1 \mathrm{v} / \mathrm{v})$ for $18 \mathrm{~h}$ at room temperature. Gel destaining was performed through continuous agitation in a methanol: acetic acid: water $(20: 10: 70 \mathrm{v} / \mathrm{v})$ solvent until obvious bands of proteins were obtained.

The whole-cell protein profiles of presumptive Listeria isolates were compared with those of the reference strains $L$. monocytogenes ATCC 19114 and L. innocua ATCC 33090 using SDSPAGE. A high degree of similarity within the standard strains was confirmed through biochemical identification using an API Listeria system. 
Biochemical identification of Listeria isolates

The biochemical identification of Listeria, using the BioMérieux API Listeria system (10300), involved a strip comprising 10 microtubes containing dehydrated substances, with each microtubule corresponding to an individual test and without additional tests. The 10 tests were arylamidase (DIM test), esculin, a-mannosidase, D-arabitol, D-xylose, L-rhamnose, a -methyl-Dglucoside, D-ribose, glucose-1-phosphate, and D-tagatose. One loop of the bacteria that was grown on nutrient agar (24 h) was suspended in $2 \mathrm{~mL}$ of sterile distilled water (BioMerieux) to a density of the MacFarland 0.5 standard. Five millilitres of sterile water were poured into the tray to create a moist atmosphere, and subsequently, the reaction strip was placed in the tray. The bacterial suspension was distributed into 10 microtubes $(100 \mu \mathrm{L}$ for the DIM test and $50 \mu \mathrm{l}$ for the other cupules). Subsequently, the strip box was closed and incubated at $37{ }^{\circ} \mathrm{C}$ for 18 to $24 \mathrm{~h}$. After incubation, the presence or absence of arylamidase (DIM test) was detected through the addition of one drop of ZYM B (ZYM $B$ reagent is used as an additional test for revealing the results of some miniaturized biochemical tests included in API Listeria (10300), and the mixture was allowed to react for $3 \mathrm{~min}$ is subsequently, the reaction results were assessed. Colour changes in reactions were determined, according to the manufacturer's instructions for the biochemical identification of Listeria.

\section{RESULTS}

\section{Incidence of Listeria spp. in different samples}

As shown in Table 1, Listeria spp. was recovered from $35 \%$ of the total tested samples (14 out of 40 samples). Fifty percent of the raw beef and chicken samples contained Listeria spp. and 30 $\%$ of the raw fish samples contained Listeria spp. Listeria spp., was observed in only $20 \%$ of the raw camel milk samples. The highest positive samples were identified as $L$. seeligrei, $L$. welshimeri and $L$. grayi $(\mathrm{n}=3,7.5 \%)$, followed by $L$. monocytogenes and $L$. innocua $(n=2 ; 5$ $\%)$. Only one sample contained L. ivanovii $(\mathrm{n}=1$, $2.5 \%)$.

\section{Whole-cell protein profiles of different Listeria species}

The protein profiles of the isolates grown on the media containing Listeria-selective agar were compared with those of standard strains of $L$. monocytogenes ATCC 19114 and L. innocua ATCC 33090 using SDS-PAGE. Fig 1 results demonstrate the presence of some common protein bands for 14 isolates, with similarities. The whole-cell protein profiling of the isolates was not closely associated with $L$. monocytogenes ATCC 19114 and L. innocua ATCC 33090, and it was difficult to differentiate between these species. The SDS-extracted protein patterns were strictly species-specific.

\section{API Listeria system}

The results of the API Listeria test were incubated for $24 \mathrm{~h}$ and interpreted using the API LAB Plus bacterial computer identification programme. Specifically, the DIM results for all strains tested were unequivocal. Carbohydrate fermentations resulting in acid production were difficult to interpret, this may occur with slow bacterial growth and the positive results of some tests were analysed based on the changing the $\mathrm{pH}$ colour [27].

\section{Haemolytic activity of Listeria spp.}

Results in Figure (2) show the hemolytic activity on blood agar sheep medium after 24 hours of incubation at $37^{\circ} \mathrm{C}$ to differentiate between the positive haemolysis of $L$. monocytogenes and $L$. seeligeri from the other Listeria spp., which were negative.

Table 1: Incidence of Listeria spp. from various high protein foods

\begin{tabular}{lcccccc}
\hline Type of meat & $\begin{array}{c}\text { Raw Beef } \\
(\mathbf{n = 1 0})\end{array}$ & $\begin{array}{c}\text { Raw Chicken } \\
(\mathbf{n}=\mathbf{1 0})\end{array}$ & $\begin{array}{c}\text { Raw Fish } \\
(\mathbf{n}=\mathbf{1 0})\end{array}$ & $\begin{array}{c}\text { Raw Carmel } \\
\mathbf{m i l k}(\mathbf{n = 1 0})\end{array}$ & $\begin{array}{c}\text { Total } \\
(\mathbf{n}=\mathbf{4 0})\end{array}$ & $\%$ \\
\hline L. monocytogenes & 0 & 2 & 0 & 0 & 2 & 5 \\
L. innocua & 1 & 1 & 0 & 0 & 2 & 5 \\
L. seeligeri & 1 & 1 & 1 & 0 & 3 & 7.5 \\
L. welshimeri & 2 & 0 & 1 & 0 & 3 & 7.5 \\
L. grayi & 1 & 0 & 1 & 1 & 3 & 7.5 \\
L. ivanovii & 0 & 1 & 0 & 0 & 1 & 2.5 \\
Total & 5 & 5 & 3 & 1 & 14 & - \\
\% & 50 & 50 & 30 & 20 & 35 & - \\
\hline
\end{tabular}




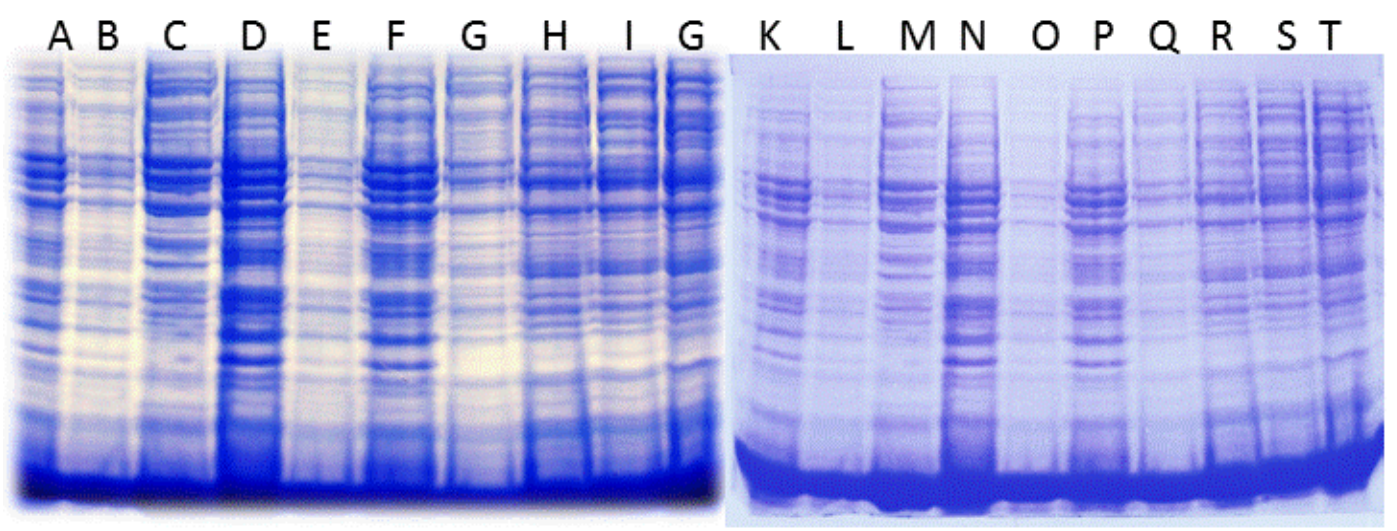

Figure 1: Whole protein profile of L. monocytogenes ATCC 19114 (Lane A), L. innocua ATCC 33090 (Lane B) and Listeria spp., isolates from different food sample (Lane, C-T)

Table 2: Identification of 15 Listeria strains with API Listeria system

\begin{tabular}{|c|c|c|c|c|c|c|}
\hline Test & $\begin{array}{c}\text { L. } \\
\text { monocytogenes } \\
(n=2)\end{array}$ & $\begin{array}{c}L . \\
\text { ivanovii } \\
(n=1)\end{array}$ & $\begin{array}{c}L . \\
\text { innocua } \\
(n=2)\end{array}$ & $\begin{array}{c}\text { L. } \\
\text { seeligeri } \\
(n=3)\end{array}$ & $\begin{array}{l}\text { L. welshimeri } \\
(n=3)\end{array}$ & $\begin{array}{l}\text { L. grayi } \\
(n=3)\end{array}$ \\
\hline DIM & - & + & + & + & + & + \\
\hline $\begin{array}{l}\text { Esculin } \\
\text { hydrolysis }\end{array}$ & + & + & + & + & - & + \\
\hline a-Mannosidase & + & + & + & - & - & + \\
\hline D-Arabitol & + & - & - & - & - & - \\
\hline D-Xylose & - & + & - & + & - & - \\
\hline L-Rhamnose & + & + & + & - & - & - \\
\hline $\begin{array}{l}\text { a-Methyl-D- } \\
\text { glucoside }\end{array}$ & + & + & + & - & - & - \\
\hline D-Ribose & - & + & - & - & - & + \\
\hline $\begin{array}{l}\text { Glucose-I } \\
\text { phosphate }\end{array}$ & - & + & - & - & - & - \\
\hline D-Tagatose & - & - & - & - & + & - \\
\hline B-Hem & + & + & - & - & - & - \\
\hline
\end{tabular}

Key: + = positive reaction; - = negative reaction

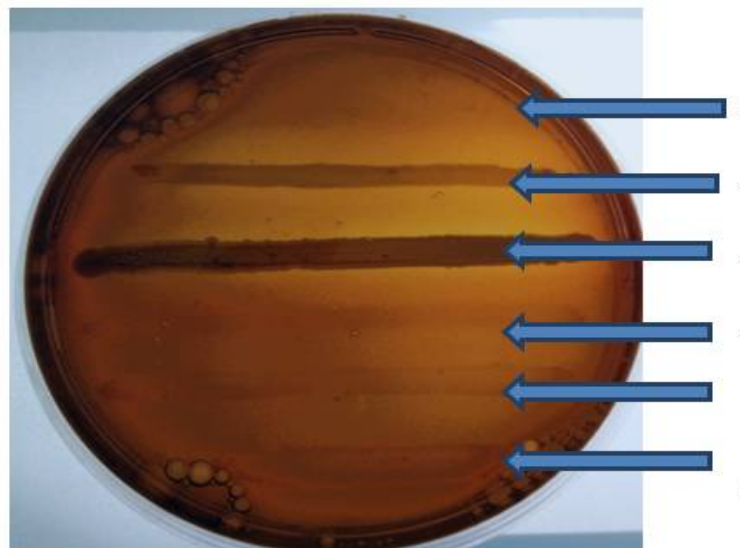

Figure 2: Hemolysis of blood sheep agar
L. innocua

L. seeligeri

\section{L. monocytogenes}

L. ivanovii

\section{L. welshimeri}

L. grayi

\section{DISCUSSION}

Raw milk was the source of the first case of foodborne listeriosis reported in 1953 in Germany, and the first listeriosis outbreak associated with milk in the United States occurred in 1979 [14]. In a similar study in Fars and Khuzestan Provinces of Iran on different milk types, the authors used culture method for the isolation of Listeria spp. They found that 19 samples $(7.3 \%)$ were positive for Listeria spp. The highest prevalence of Listeria was found in raw water buffalo milk 
(11.8\%), followed by raw bovine milk (10.6\%), raw ovine milk (7.1\%), and raw caprine milk (4.2 $\%$ ) samples. All 37 camel milk samples from 20 camel breeding farms were negative for Listeria spp. Kosek-Paszkowska et al [22], detected Listeria spp. in 36 samples of raw chicken parts $(51.4 \%)$ and 7 samples of poultry minced meat $(30.4 \%)$. L. monocytogenes was also detected in these samples (5 and 1 samples, respectively). The predominant species among the isolated Listeria strains was $L$. innocua, which was detected in 27 samples (63\%), followed by $L$. welshimeri (7 samples - $16 \%)$, L. grayi (2 samples $-5 \%$ ) and $L$. seeligeri (1 sample -2 $\%)$.

These results demonstrate the significance of equipment and installations as sources of Listeria spp. and $L$. monocytogenes contaminations in the processing of beef and meat products. Microbiologically analysed Listeria species and $L$. monocytogenes contamination in fermented fish and meat samples purchased from the supermarket and the wet market. Listeria species were isolated from $17(73.9 \%)$ of the 23 samples of imported frozen beef, $10(43.5 \%)$ of the 23 samples of local beef and $14(56 \%)$ of the 25 samples of fermented fish obtained from the wet market. L. monocytogenes occurred in $15(75 \%)$ of the frozen beef samples, $6(30.4 \%)$ of the 23 samples of local meat and $3(12 \%)$ of the 25 samples from fermented fish. Listeria species were not isolated from any of the 23 samples of imported frozen beef obtained from the supermarket and the 5 samples of buffalo meat examined [23].

Only a few major bands appeared common to all species, and these bands were primarily located in the lower part of the gel. Large differences were observed between the protein profiles of $L$. monocytogenes, $L$. innocua, $L$. seeligeri, $L$. ivanovii and $L$. welshimeri, and L. grayi. The representation of these differences was assessed through the calculation of the average similarity, S, through visual comparisons. Despite the method of visual comparison, adequate reproducibility was obtained because of the high resolution of the gels. Analysis of the clusters confirmed the clear distinction between $L$. monocytogenes and the other species ( $S=51$ $\%$ ). Some isolates could not be analysed because there was not a sufficient proteins yield after extraction or the observed bands did not resemble $L$. monocytogenes ATCC 19114 and $L$. innocua ATCC 33090. Any isolates showing discrepancies in the protein profile were excluded from confirmation of identification using the API Listeria system.
API $50 \mathrm{CH}$ system successfully used for the identification of Listeria species through the selection of the markers currently used on the API Listeria strip. Rapid and inexpensive identification scheme that relies on the detection of haemolysis and two-carbohydrate (Lrhamnose and $D$-xylose) fermentation tests were performed on agar plates with one isolated colony growing on selective lithium chlorideceftazidime agar plates after a 40-h incubation. Haemolysis can be difficult to assess; thus, various atypical $L$. monocytogenes strains (nonhaemolytic, catalase negative, rhamnose negative, and nonmotile) would not be identified.

The identification of Listeria species has long been hampered through the small number of tests facilitating the differentiation between these closely related species; numerical phenetic studies did not solve this crucial problem. With the conditions described here, the API Listeria test provided three new markers: the fermentation of D-tagatose for $L$. welshimeni and glucose-1-phosphate for L. ivanovii (replacing the CAMP test with R. equi) and DIM (avoiding the need for the CAMP test with Staphylococcus aureus). DIM is a new test based on the detection of arylamidase, which is present in $L$. innocua and a majority of other non- $L$. monocytogenes strains but is absent in $L$. monocytogenes strains.

Spontaneous haemolysis, a major characteristic for Listeria species identification, may, in some cases (particularly for environmental and food isolates), be difficult to read on blood agar plates when differentiating $L$. monocytogenes from $L$. innocua. To circumvent this important problem, more sensitive methods, such as the use of microtitre plates, a CAMP test with $S$. aureus, or tests for pathogenicity have been suggested. Nevertheless, even with these tests, some true non-haemolytic $L$. monocytogenes isolates may be misidentified as $L$. innocua on the basis of their phenotypic behaviour. Lytic zones were observed on sheep blood agar, weak reaction which did not extend the edge of the streaking line as for $L$. monocytogenes. L. innocua strains were not haemolytic, while $L$. ivanovii produced clear zones of haemolysis on blood sheep agar.

L. welshimeri and L. seeligeri are well established as nonhaemolytic virulent species [3]. To date, only genomic methods can firmly identify these isolates. With DIM test, all of the $L$. monocytogenes strains studied thus far, including atypical non-haemolytic isolates, have been easily and clearly distinguished from $L$. innocua. Therefore, this test unambiguously 
improves the speed and accuracy of species identification.

\section{CONCLUSION}

Six species of Listeria were found in different protein foods, but the real threat to consumer health is only Listeria monocytogenes which was isolated from only one sample, namely, chicken meat which is often associated with this pathogen and is destroyed by proper cooking of the meat. The high percentage of Listeria spp. isolated from different food samples is noteworthy.

Polyacrylamide gel electrophoresis (PAGE) of Listeria spp., proteins is an efficient technique for the classification of strains occurring in foods, based on phenotypical characteristics expressed by their protein profiles and can related directly to API Listeria system for verification of its positive reaction rapidly and easily.

\section{ACKNOWLEDGEMENT}

The authors would like to express their sincere appreciation to Deanship of Scientific Research at King Saud University for funding of this research through Research Group Project no. RG-1435-016.

\section{CONFLICT OF INTEREST}

No conflict of interest associated with this work.

\section{CONTRIBUTION OF AUTHORS}

We declare that this work was done by the authors named in this article and all liabilities pertaining to claims relating to the content of this article will be borne by the authors.

\section{REFERENCES}

1. Seeliger HPR, Jones D. Genus Listeria Pirie. 1940, 383. In: 379 Bergey's Manual of Systemic Bacteriology, vol. 2, Sneath, Mair, Sharpe and Holt (Eds). Williams and Wilkins: Baltimore, MD; 1986.

2. Busch LA. New From the Center for Disease Control Human Listeriosis in the United States, 1967-1969. J Infec Dis 1971; 123: 328-332.

3. Rocourt J, Seeliger HPR. Classification of a Different Listeria species. Zbl Bakterool Hyg A 1985; 259: $317-$ 330.

4. Hof $H$, Rocourt $J$ Is any strain of Listeria monocytogenes detected in food a health risk? Int J Food Microbiol 1992; 16: 173-182
5. McLauchlin, J. Listeriosis and Listeria monocytogenes. Environ Policy \& Prac 1993; 3, 201-214.

6. Swaminathan B. Listeria monocytogenes. In Food Microbiology Fundamentals and Frontiers, 2nd edn, Doyle MP, Beuchat LR, Montville TJ. Washington, DC: ASM Press; 2001; pp. 383-409.

7. Farber JM, Peterkin PI. Listeria monocytogenes, a foodborne pathogen. Mcrobiol Rev 1991; 55: 476-511.

8. Hofer E. Study on Listeria spp. on vegetables suitable for human consumption. In Congresso Brasileiro de Microbiologia, Salvador, Brasil; 1975.

9. Hofer E, Ribeiro R. Ocorre ncia de espe cies de Listeria 333 em camara o industrializado Rev Microbiol 1990; 21(2): 207-208.

10. Destro MT, Serrano AM, Kabliki DY. Isolation of Listeria species from some Brazilian meat and dairy products. Food Control 1991; 2: 110-112.

11. Silva MCD, Hofer E, Tibana A. Incidence of Listeria monocytogenes in cheese produced in Rio de Janeiro, Brazil. J Food Protect 1998; 61(3): 354-356.

12. Hofer E. Isolation and characterization of Listeria monocytogenes in Sewage. Mem I Os Cr 1975b; 73: 31-38.

13. Hofer E, Po voa, MM. Study of Listeria monocytogenes in soil. Mem I Os Cr 1984; 79(1): 45-53.

14. Ryser ET. Foodborne listeriosis. In E. T. Ryser \& E. H. Marth (Eds.), Listeria, Listeriosis and Food Safety (2nd ed., pp. 258-299). New York: Marcel Dekker. Occurrence of Listeria $s p$. in raw poultry meat and poultry meat products. B Vet I Pulawy 1999; 49(2): 219222.

15. Rahimi E, Momtaz H, Behzadnia A, Zeinab TB. Incidence of Listeria species inbovine, ovine, caprine, camel and water buffalo milk using cultural method and the PCR assay. Asian Pacific J Trop Dis. Asian Pac J Trop Dis 2014; 4(1): 50-53.

16. Allerberger F. Listeria: growth, phenotypic differentiation and molecular microbiology. FEMS Immunol. Med Microbiol 2003; 35: 183-189.

17. Buncic, S. The incidence of Listeria monocytogenes in slaughtered animals, in meat, and in meat products in Yugoslavia. Int J Food Microbiol 1991; 12: 173-180.

18. Uyttendaele, M, Troy PD, Debevere J. Incidence of Listeria monocytogenes in different types of meat products on the Belgian retail market. Int $J$ Food Microbiol 1999; 53: 75-80.

19. Hudson, JA, Mott SJ, Delacy KM, Edridge AL. Incidence and coincidence of Listeria spp. motile aeromonads and Yersinia enterocolitica on ready-to-eat flesh foods. Int $J$ Food Microbiol 1992; 16: 99-108.

20. Ibrahim A, Mac Rae IC. Incidence of Aeromonas and Listeria spp. in red meat and milk samples in Brisbane Australia. Int J Food Microbiol 1991; 12: 263-270.

21. Ryu $\mathrm{CH}$, Igimi $S$, Inoue $S$, Kumagai $S$. The incidence of Listeria species in retail foods in Japan Int $J$ Food Microbiol 1992; 16: 157-160.

22. Kosek-Paszkowska K, Bania J, Bystron J, Molenda J, Czerw M. Occurrence of Listeria sp. in raw poultry meat

Trop J Pharm Res, May 2016; 15(5): 1052 
Yehia et al

and poultry meat products. B Vet IPulawy 2005; 49(2): 219-222.

23. Hassan Z, Endang, PE, Abdul-Rahim, SR, Rusul, G. Prevalence of Listeria spp and Listeria monocytogenes in meat and fermented fish in Malaysia. Southeast Asian $J$ Trop. Med. Public Health 2001; 32 (2): 402-407. 